\title{
Stimulation of Erythrocyte Cell Membrane Scrambling by Gedunin
}

\author{
Adrian Lupescu Rosi Bissinger Jamshed Warsi Kashif Jilani Florian Lang \\ Department of Physiology, University of Tübingen, Germany
}

\section{Key Words}

Phosphatidylserine $\bullet$ Gedunin $•$ Calcium $•$ Malaria $•$ Anemia $•$ Cell volume $•$ Eryptosis

\begin{abstract}
Background/Aims: Gedunin, an inhibitor of heat shock protein HSP90, triggers apoptosis of tumor cells and is thus effective against malignancy. Moreover, the drug has antimalarial potency. In analogy to apoptosis of nucleated cells, erythrocytes may enter suicidal death or eryptosis, which is characterized by cell shrinkage and by phosphatidylserine translocation to the erythrocyte surface. Eryptosis may be triggered by increase of cytosolic $\mathrm{Ca}^{2+}$-activity $\left(\left[\mathrm{Ca}^{2+}\right]_{\mathrm{i}}\right)$. The present study explored whether gedunin stimulates eryptosis. Methods: Forward scatter was determined to estimate cell volume, annexin $\mathrm{V}$ binding to identify phosphatidylserine-exposing erythrocytes, hemoglobin release to depict hemolysis, and Fluo3-fluorescence to quantify $\left[\mathrm{Ca}^{2+}\right]_{\text {. }}$. Results: A $48 \mathrm{~h}$ exposure of human erythrocytes to gedunin significantly increased $\left[\mathrm{Ca}^{2+}\right]_{i}(12 \mu \mathrm{M})$, significantly decreased forward scatter $(24$ $\mu \mathrm{M})$ and significantly increased annexin-V-binding $(12 \mu \mathrm{M})$. The effect of gedunin $(24 \mu \mathrm{M})$ on annexin-V-binding was virtually abrogated by removal of extracellular $\mathrm{Ca}^{2+}$. Conclusion: Gedunin stimulates suicidal erythrocyte death or eryptosis, an effect mainly if not exclusively due to stimulation of $\mathrm{Ca}^{2+}$ entry.
\end{abstract}

\section{Introduction}

Gedunin $\quad((1 S, 3 \mathrm{a} S, 4 \mathrm{a} R, 4 \mathrm{~b} S, 5 R, 6 \mathrm{a} R, 10 \mathrm{a} R, 10 \mathrm{~b} R, 12 \mathrm{a} S)-5$-(Acetyloxy)-1-(3-furanyl)1,5,6,6a,7, 10a,10b,11,12,12a,decahydro-4b,7,7,10a,12a,-pentamethyloxireno[c]phenanthro [1,2-d]pyran-3,8 (3aH,4bH)-dione, Fig.1), a component of oleum azadirachti from dried seeds 
of Azadirachta indica A. Juss. (family: Meliaceae) [1], has been shown to inhibit heat shock protein HSP90 thus triggering apoptosis of tumor cells [2-6]. The substance has thus been considered for the treatment of malignancy $[3,4,6,7]$. Mechanisms invoked in the triggering of tumor cell apoptosis following gedunin treatment include inhibition of the antiapoptotic protein HSP90 and downregulation of the anti-apoptotic proteins HSP70 and HSP27 [3], activation of the caspases 3, 8, and 9 [8] and inhibition of sphingomyelin biosynthesis [9]. Gedunin has further been shown to be effective in vitro against Plasmodium falciparum [1014]. The target accounting for the effects of gedunin on parasites remained illdefined.

In analogy to apoptosis of nucleated cells, erythrocytes may enter suicidal death or eryptosis, which is characterized by cell membrane scrambling and cell shrinkage [15]. Triggers of eryptosis include increase of cytosolic $\mathrm{Ca}^{2+}$ concentration $\left(\left[\mathrm{Ca}^{2+}\right]_{\mathrm{i}}\right)$, e.g. following $\mathrm{Ca}^{2+}$ entry through $\mathrm{Ca}^{2+}$-permeable cation channels [15]. Increased $\left[\mathrm{Ca}^{2+}\right]_{\mathrm{i}}$ activates $\mathrm{Ca}^{2+}$ sensitive $\mathrm{K}^{+}$channels leading to cell shrinkage due to $\mathrm{K}^{+}$exit, hyperpolarization, $\mathrm{Cl}^{-}$exit and thus cellular loss of $\mathrm{KCl}$ and osmotically obliged water [16]. Increased $\left[\mathrm{Ca}^{2+}\right]_{\mathrm{i}}$ further triggers phospholipid scrambling of the cell membrane with translocation of phosphatidylserine to the erythrocyte surface [15]. Signaling in the regulation of eryptosis includes in addition ceramide formation [15], caspase activation [17-21] and deranged regulation of several kinases such as AMP activated kinase AMPK [22], casein kinase $1 \alpha$ [23, 24], cGMP-dependent protein kinase [25], Janus-activated kinase JAK3 [26], protein kinase C [27], p38 kinase [28], PAK2 kinase [29] as well as sorafenib [30] and sunitinib [31] sensitive kinases.

Eryptosis may be stimulated by a wide variety of xenobiotics [15, 31-66] and excessive eryptosis is further observed in several clinical conditions including diabetes, renal insufficiency, hemolytic uremic syndrome, sepsis, malaria, sickle cell disease, Wilson's disease, iron deficiency, malignancy, phosphate depletion, and metabolic syndrome [15].

Erythrocytes have previously been shown to express HSP90 [67, 68] and eryptosis could be stimulated by the HSP90 inhibitor geldanamycin [60].

The present study thus explored, whether and how gedunin influences eryptosis. To this end, $\left[\mathrm{Ca}^{2+}\right]_{\mathrm{i}}$, cell volume and phosphatidylserine translocation to the erythrocyte surface were determined in the absence and presence of gedunin.

\section{Materials and Methods}

Erythrocytes, solutions and chemicals

Erythrocytes were kindly provided by the blood bank of the University of Tübingen. For retriveal of leukocyte-free erythrocyte concentrates, citrate was used as anticoagulant. Prior to experiments, the concentrates were stored at $4{ }^{\circ} \mathrm{C}$ in the commonly-used SAG mannitol solution $(0.41-0.26 \mathrm{ml} / \mathrm{ml}$ concentrate) with CPD stabilisator solution (0.015 - $0.007 \mathrm{ml} / \mathrm{ml}$ concentrate). $100 \mathrm{ml}$ SAG mannitol solution contained $0.877 \mathrm{~g} \mathrm{NaCl}, 0.9 \mathrm{~g}$ glucose, $0.0169 \mathrm{~g}$ adenosine, $0.525 \mathrm{~g}$ mannitol. Hundred ml CPD stabilisator solution contained $0.327 \mathrm{~g}$ citric acid monohydrate, 2.63 g sodium citrate, 2.55 g glucose monohydrate, $0.251 \mathrm{~g}$ sodium dihydrogenphosphate. The erythrocyte concentrates were 7 - 20 days old when starting the experiment. The study is approved by the ethics committee of the University of Tübingen $(184 / 2003 V)$. Erythrocytes were incubated in vitro at a hematocrit of $0.4 \%$ in Ringer solution containing (in $\mathrm{mM}) 125 \mathrm{NaCl}, 5 \mathrm{KCl}, 1 \mathrm{MgSO}_{4}, 32 \mathrm{~N}$-2-hydroxyethylpiperazine-N-2-ethanesulfonic acid (HEPES), 5 glucose, $1 \mathrm{CaCl}_{2} ; \mathrm{pH} 7.4$ at $37^{\circ} \mathrm{C}$ for $48 \mathrm{~h}$. Where indicated, erythrocytes were exposed to gedunin (Tocris, Bristol, U.K.) at the indicated concentrations. In $\mathrm{Ca}^{2+}$-free Ringer solution, $1 \mathrm{mM} \mathrm{CaCl}$, was substituted by $1 \mathrm{mM}$ glycol-bis(2-aminoethylether)-N,N,N',N'-tetraacetic acid (EGTA). Gedunin was added from a stock solution $(10 \mathrm{mM})$ dissolved in DMSO. The maximal final concentration of solvent was $2.4 \mu \mathrm{l}$.

\section{FACS analysis of annexin-V-binding and forward scatter}

After incubation under the respective experimental condition, $50 \mu \mathrm{l}$ cell suspension was washed in Ringer solution containing $5 \mathrm{mM} \mathrm{CaCl}_{2}$ and then stained with Annexin-V-FITC (1:200 dilution; ImmunoTools, Friesoythe, Germany) in this solution at $37^{\circ} \mathrm{C}$ for $20 \mathrm{~min}$ under protection from light. In the following, the forward scatter (FSC) of the cells was determined, and annexin-V fluorescence intensity was measured 
with an excitation wavelength of $488 \mathrm{~nm}$ and an emission wavelength of $530 \mathrm{~nm}$ on a FACS Calibur (BD, Heidelberg, Germany). Alterations of forward scatter are paralleled by similar alterations of mean erythrocyte volume (MCV) [69]. No attempt was made to calculate mean erythrocyte cell volume from forward scatter.

\section{Measurement of intracellular $\mathrm{Ca}^{2+}$}

After incubation erythrocytes were washed in Ringer solution and then loaded with Fluo-3/ AM (Biotium, Hayward, USA) in Ringer solution containing $5 \mathrm{mM} \mathrm{CaCl}_{2}$ and $5 \mu \mathrm{M}$ Fluo-3/AM. The cells were incubated at $37^{\circ} \mathrm{C}$ for $30 \mathrm{~min}$ and washed

Fig. 1. Structure of gedunin.

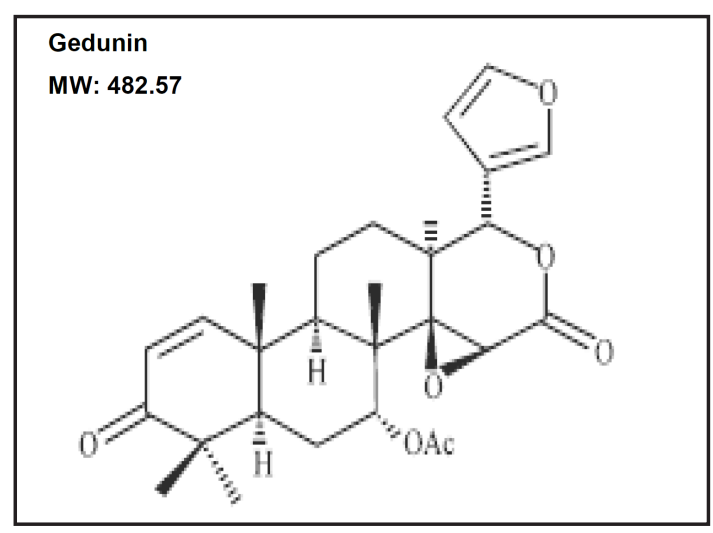
twice in Ringer solution containing $5 \mathrm{mM} \mathrm{CaCl}_{2}$. The Fluo-3/AM-loaded erythrocytes were resuspended in $200 \mu$ Ringer. Then, $\mathrm{Ca}^{2+}$-dependent fluorescence intensity was measured with an excitation wavelength of $488 \mathrm{~nm}$ and an emission wavelength of $530 \mathrm{~nm}$ on a FACS Calibur. As shown in previous papers [70], alterations of $\mathrm{Ca}^{2+}$ uptake leading to respective alterations of Fluo3 fluorescence are paralleled by similar alterations of radioactive $\mathrm{Ca}^{2+}$ fluxes. Alterations of Fluo3 fluorescence thus reflect alterations of cytosolic $\mathrm{Ca}^{2+}$ activity. However, the dye does not allow ratiometric measurements and thus does not allow calculating cytosolic $\mathrm{Ca}^{2+}$ activity.

\section{Determination of ceramide formation}

For the determination of ceramide, a monoclonal antibody-based assay was used. After incubation, cells were stained for 1 hour at $37^{\circ} \mathrm{C}$ with $1 \mu \mathrm{g} / \mathrm{ml}$ anti ceramide antibody (clone MID 15B4, Alexis, Grünberg, Germany) in PBS containing $0.1 \%$ bovine serum albumin (BSA) at a dilution of 1:10. The samples were washed twice with PBS-BSA. Subsequently, the cells were stained for 30 minutes with polyclonal fluorescein isothiocyanate (FITC) conjugated goat anti-mouse IgG and IgM specific antibody (Pharmingen, Hamburg, Germany) diluted 1:50 in PBS-BSA. Unbound secondary antibody was removed by repeated washing with PBS-BSA. The samples were then analyzed by flow cytometric analysis with an excitation wavelength of 488 $\mathrm{nm}$ and an emission wavelength of $530 \mathrm{~nm}$.

\section{Statistics}

Data are expressed as arithmetic means \pm SEM. As indicated in the figure legends, statistical analysis was made using ANOVA with Tukey's test as post-test and $t$ test as appropriate. $\mathrm{n}$ denotes the number of different erythrocyte specimens studied. Since different erythrocyte specimens used in distinct experiments are differently susceptible to triggers of eryptosis, the same erythrocyte specimens have been used for control and experimental conditions.

\section{Results}

The present study explored the putative effect of gedunin on eryptosis, the suicidal erythrocyte death characterized by cell shrinkage and cell membrane scrambling, both events stimulated by increase of cytosolic $\mathrm{Ca}^{2+}$ activity $\left(\left[\mathrm{Ca}^{2+}\right]_{\mathrm{i}}\right)$.

In a first series of experiments, forward scatter was determined in flow cytometry as a measure of cell volume. Prior to measurements, erythrocytes were incubated in Ringer solution without or with gedunin $(2-24 \mu \mathrm{M})$. As shown in Fig. 2, a $48 \mathrm{~h}$ exposure to gedunin was followed by a slight decrease of forward scatter, an effect reaching statistical significance at $24 \mu \mathrm{M}$ gedunin concentration. Thus, exposure of erythrocytes to gedunin was followed by erythrocyte shrinkage.

The decrease of forward scatter could have resulted from activation of $\mathrm{Ca}^{2+}$-sensitive $\mathrm{K}^{+}$channels with subsequent cell shrinkage due to exit of $\mathrm{KCl}$ and osmotically obliged water. Thus, the effect of gedunin on $\left[\mathrm{Ca}^{2+}\right]_{\mathrm{i}}$ was tested. Human erythrocytes were loaded with 


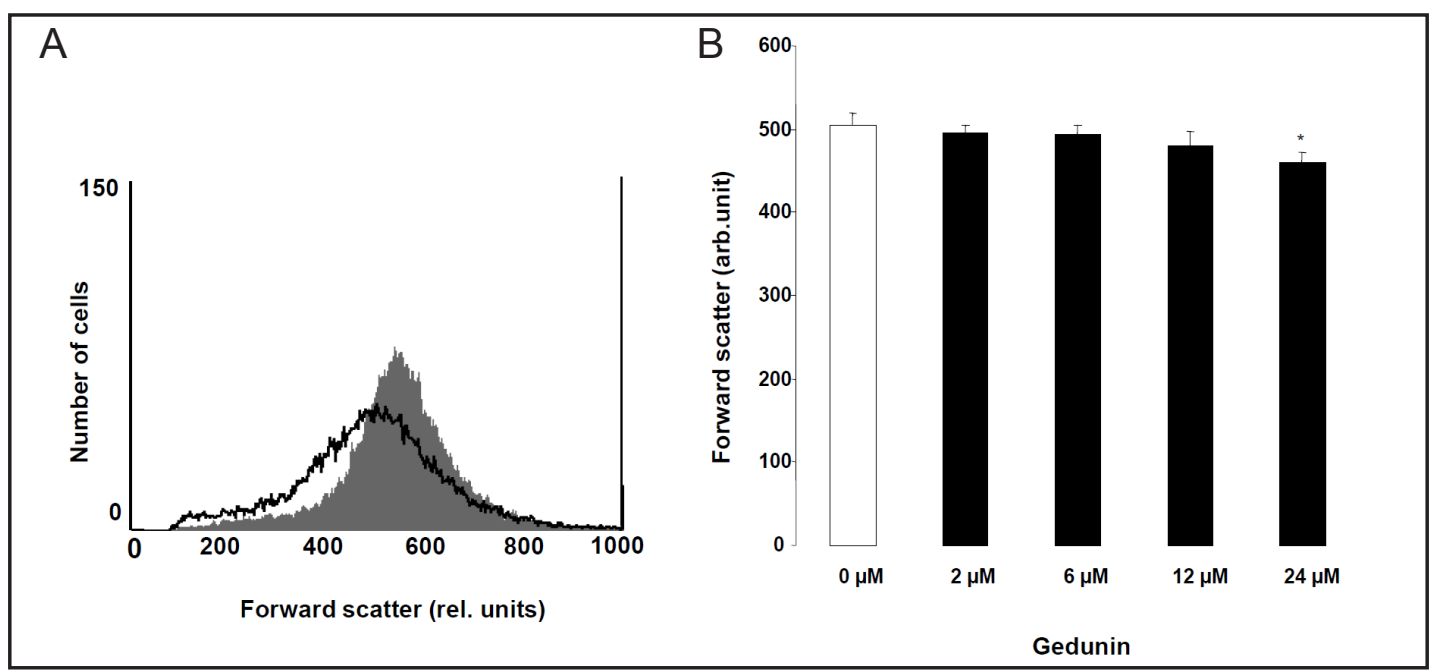

Fig. 2. Effect of gedunin on erythrocyte forward scatter. A. Original histogram of forward scatter of erythrocytes following exposure for $48 \mathrm{~h}$ to Ringer solution without (grey area) and with (black line) presence of $24 \mu \mathrm{M}$ gedunin. B. Arithmetic means \pm SEM $(n=8)$ of the normalized erythrocyte forward scatter (FSC) following incubation for $48 \mathrm{~h}$ to Ringer solution without (white bar) or with (black bars) gedunin $(2-24 \mu \mathrm{M}) .{ }^{*}(\mathrm{p}<0.05)$ indicates significant difference from the absence of gedunin (ANOVA).

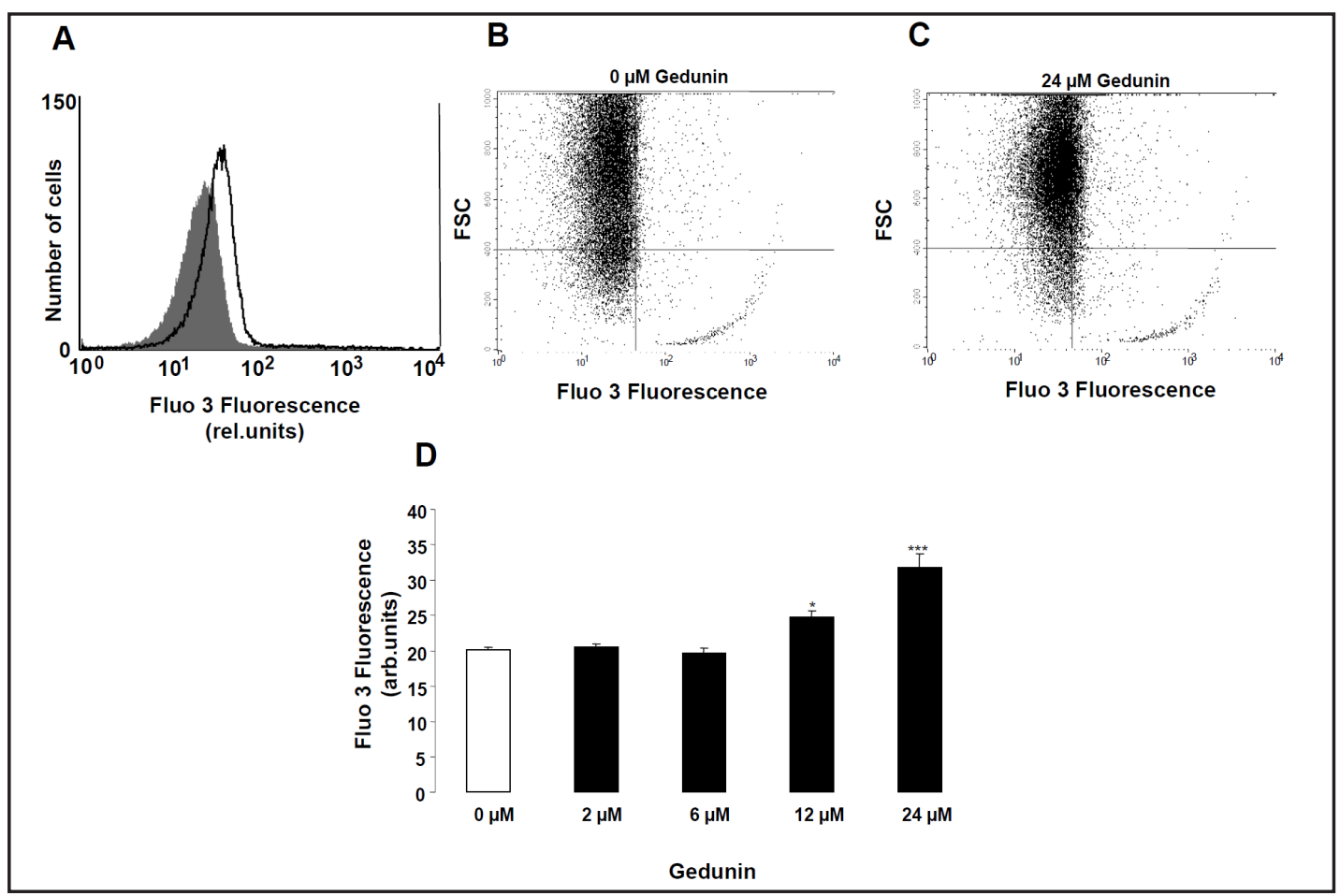

Fig. 3. Effect of gedunin on erythrocyte cytosolic $\mathrm{Ca}^{2+}$ concentration. A. Original histogram of Fluo3 fluorescence in erythrocytes following exposure for $48 \mathrm{~h}$ to Ringer solution without (grey area) and with (black line) presence of $24 \mu \mathrm{M}$ gedunin. B,C. Original dot blots of annexin $\mathrm{V}$ binding as a function of forward scatter following exposure for $48 \mathrm{~h}$ to Ringer solution without (B) and with (C) presence of $24 \mu \mathrm{M}$ gedunin. D. Arithmetic means \pm SEM $(n=8)$ of the Fluo3 fluorescence (arbitrary units) in erythrocytes exposed for 48 $\mathrm{h}$ to Ringer solution without (white bar) or with (black bars) gedunin $(2-24 \mu \mathrm{M}){ }^{*}(\mathrm{p}<0.05),{ }^{* * *}(\mathrm{p}<0.001)$ indicate significant difference from the absence of gedunin (ANOVA).

Fluo3-AM and the Fluo3 fluorescence determined by flow cytometry. Prior to determination of Fluo3-fluorescence, erythrocytes were incubated in Ringer solution without or with 


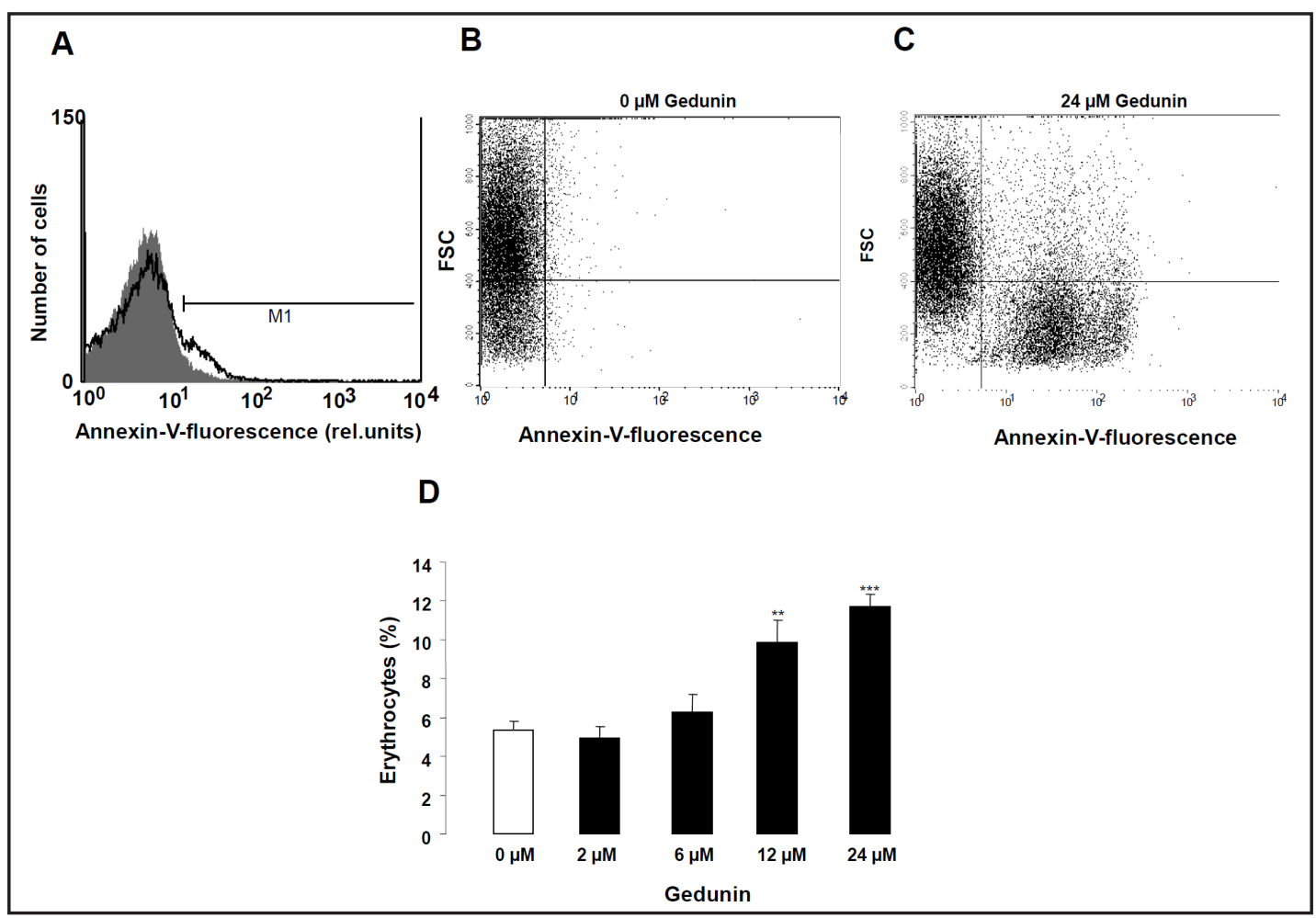

Fig. 4. Effect of gedunin on phosphatidylserine exposure. A. Original histogram of annexin-V-binding of erythrocytes following exposure for $48 \mathrm{~h}$ to Ringer solution without (grey area) and with (black line) presence of $24 \mu \mathrm{M}$ gedunin. B,C. Original dot blots of annexin V binding as a function of forward scatter following exposure for $48 \mathrm{~h}$ to Ringer solution without (B) and with (C) presence of $24 \mu \mathrm{M}$ gedunin. D. Arithmetic means \pm SEM of erythrocyte annexin-V-binding $(n=8)$ following incubation for $48 \mathrm{~h}$ to Ringer solution without (white bar) or with (black bars) presence of gedunin $(2-24 \mu \mathrm{M}){ }^{* *}(\mathrm{p}<0.01),{ }^{* * *}(\mathrm{p}<0.001)$ indicate significant difference from the absence of gedunin (ANOVA).

gedunin $(2-24 \mu \mathrm{M})$. As shown in Fig. 3, a $48 \mathrm{~h}$ exposure of human erythrocytes to gedunin increased Fluo3 fluorescence, an effect reaching statistical significance at $12 \mu \mathrm{M}$ gedunin concentration. Thus, gedunin increased cytosolic $\mathrm{Ca}^{2+}$ concentration.

An increase of $\left[\mathrm{Ca}^{2+}\right]_{\mathrm{i}}$ is known to stimulate cell membrane phospholipid scrambling leading to phosphatidylserine translocation to the erythrocyte surface. In order to identify phosphatidylserine exposing erythrocytes, annexin-V-binding was determined in flow cytometry. As shown in Fig. 4, a 48 h exposure to gedunin increased the percentage of annexin-V-binding erythrocytes, an effect reaching statistical significance at $12 \mu \mathrm{M}$ gedunin. Thus, gedunin triggered erythrocyte cell membrane scrambling with phosphatidylserine translocation to the cell surface.

In order to quantify the effect of gedunin on hemolysis, the percentage of hemolysed erythrocytes was estimated from hemoglobin concentration in the supernatant. As a result, the percentage of hemolysed erythrocytes approached $0.21 \pm 0.07 \%, 0.86 \pm 0.50 \%, 1.2 \pm$ $0.85 \%, 3.4 \pm 1.6 \%$ and $5.2 \pm 1.6 \%$ following exposure of erythrocytes for $48 \mathrm{~h}$ to $0,2,6,12$ and $24 \mu$ M gedunin $(n=4)$.

A further series of experiments tested whether the gedunin induced cell membrane scrambling required entry of extracellular $\mathrm{Ca}^{2+}$. To this end, erythrocytes were exposed to $24 \mu \mathrm{M}$ gedunin for $48 \mathrm{~h}$ in the presence and in the nominal absence of extracellular $\mathrm{Ca}^{2+}$. As shown in Fig. 5, the effect of gedunin on annexin-V-binding was virtually abrogated in the nominal absence of $\mathrm{Ca}^{2+}$. Thus, the effect of gedunin was mainly if not exclusively due to $\mathrm{Ca}^{2+}$ entry. 
Fig. 5. Effect of $\mathrm{Ca}^{2+}$ withdrawal on gedunin- induced annexin-V-binding. Arithmetic means \pm SEM $(n=4)$ of the percentage of annexin-V-binding erythrocytes after a $48 \mathrm{~h}$ treatment with Ringer solution without (white bars) or with (black bars) $24 \mu \mathrm{M}$ gedunin in the presence (left bars) and absence (right bars) of calcium. ${ }^{* * *}(\mathrm{p}<0.001)$ indicates significant difference from the respective values in absence of gedunin, \#\#\# ( $\mathrm{p}<0.001)$ indicates significant difference from the respective value in the presence of $\mathrm{Ca}^{2+}$ (ANOVA).

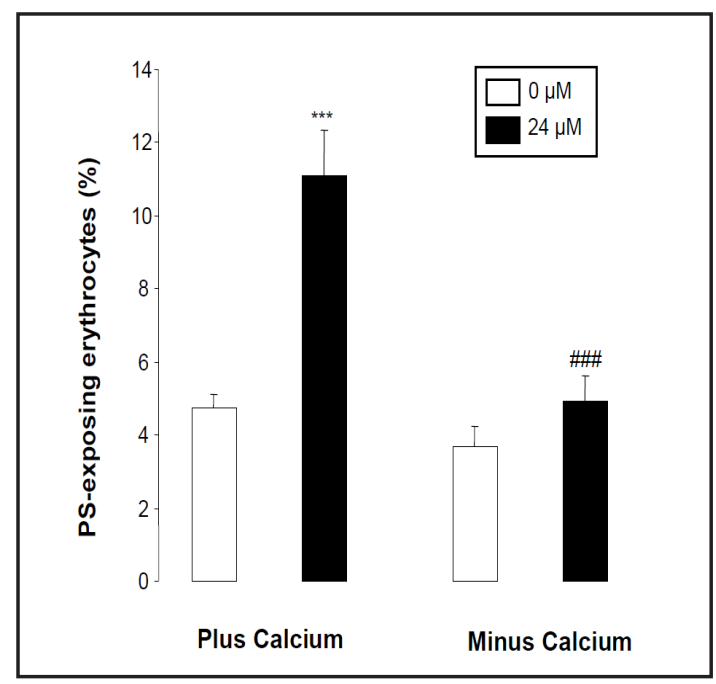

Additional experiments were made on the effect of gedunin on ceramide formation. Following a 48 hour incubation with or without $24 \mu \mathrm{M}$ gedunin, the ceramide abundance at the erythrocyte surface was $13.4 \pm 3.1(n=4)$ in the absence and $13.8 \pm 2.6(n=4)$ in the presence of gedunin, values not significantly different.

\section{Discussion}

The present study discloses a novel effect of gedunin, i.e. stimulation of erythrocyte cell membrane scrambling leading to phosphatidylserine translocation to the erythrocyte surface. Treatment of human erythrocytes with gedunin further decreased cell volume and increased cytosolic $\mathrm{Ca}^{2+}$ activity $\left(\left[\mathrm{Ca}^{2+}\right]_{\mathrm{i}}\right)$. The concentrations required for those effects were similar to those encountered in vivo [14].

Erythrocytes express HSP $90[67,68]$ and the HSP 90 inhibitor geldanamycin has previously been shown to trigger eryptosis [60]. To the best of our knowledge this is the first demonstration that gedunin increases cytosolic $\left[\mathrm{Ca}^{2+}\right]_{\mathrm{i}}$. Notably, both, HSP90 and transient receptor potential channels, interact with XPORT (exit protein of rhodopsin and TRP) [71] and HSP90 may thus, at least in theory, modify the function of the erythrocyte cation channel, which involves TRPC6 [15]. The increase of $\left[\mathrm{Ca}^{2+}\right]_{\mathrm{i}}$ presumably accounts for the erythrocyte shrinkage. Increased $\left[\mathrm{Ca}^{2+}\right]_{\mathrm{i}}$ activates $\mathrm{Ca}^{2+}$ sensitive $\mathrm{K}^{+}$channels [15] followed by $\mathrm{K}^{+}$exit, cell membrane hyperpolarisation, $\mathrm{Cl}^{-}$exit and thus cellular loss of $\mathrm{KCl}$ with osmotically obliged water [16]. The decrease of cell volume during eryptosis counteracts swelling of defective erythrocytes, which may otherwise lead to rupture of the erythrocyte membrane with subsequent cellular release, glomerular filtration and intratubular precipitation of hemoglobin [72].

Stimulation of $\mathrm{Ca}^{2+}$ entry may possibly contribute to the stimulation of apoptosis by gedunin. Increased $\left[\mathrm{Ca}^{2+}\right]_{\mathrm{i}}$ is a well known trigger of apoptosis in nucleated cells [73-75]. Further experiments in nucleated cells are warranted to explore whether gedunin increases $\left[\mathrm{Ca}^{2+}\right]_{\mathrm{i}}$ similarly in tumor cells and, if so, whether this effect participates in the triggering of apoptosis.

The stimulation of cell membrane scrambling with phosphatidylserine exposure at the cell surface may be favourable during infection with the malaria pathogen Plasmodium falciparum. In view of its effect on noninfected cells gedunin may accelerate suicidal death of infected erythrocytes [76]. The intraerythrocytic parasite activates several channels including $\mathrm{Ca}^{2+}$-permeable erythrocyte cation channels $[77,78]$. The channels provide the intraerythrocytic pathogen with nutrients, $\mathrm{Na}^{+}$and $\mathrm{Ca}^{2+}$ and allow the disposal of waste products [78]. Intraerythrocyte survival of the pathogen thus requires activation of those channels $[77,78]$. The $\mathrm{Ca}^{2+}$ entry through the $\mathrm{Ca}^{2+}$-permeable cation channels triggers, however, eryptosis [76], thus leading to rapid clearance of the infected erythrocytes from 
circulating blood [15]. Accordingly, $\mathrm{Ca}^{2+}$ entry and subsequent eryptosis limits the life span of infected erythrocytes and thus counteracts parasitemia [76]. Along those lines several genetic disorders predisposing to accelerated eryptosis, such as sickle-cell trait, beta-thalassemiatrait, homozygous Hb-C and G6PD-deficiency [15] are known to confer partial resistance to malaria [79-81], even though the partial resistance may involve further mechanisms other than eryptosis [82-85].

In addition to genetic erythrocyte disorders, several clinical conditions and drugs stimulating eryptosis have been shown to favourably influence the clinical course of malaria, such as iron deficiency [86], lead [87], chlorpromazine [88] and inhibition of NO synthase [89].

On the other hand, stimulation of eryptosis may lead to anemia. Phosphatidylserine at the surface of eryptotic cells binds to the respective receptors of phagocytosing cells thus leading to rapid removal of the suicidal erythrocytes from circulating blood [15]. As soon as accelerated loss of erythrocytes during stimulated eryptosis cannot be matched by similarly enhanced formation of new erythrocytes, anemia develops [15]. Phosphatidylserine exposing erythrocytes may further impede microcirculation [90-95], as they adhere to endothelial CXCL16/SR-PSO [91]. Phosphatidylserine exposing erythrocytes may further stimulate blood clotting and thrombosis $[90,96,97]$.

Whether or not gedunin and/or HSP90 inhibition leads to anemia and/or deranged microcirculation, remains to be established. In HSP90 knockout mice enhanced antibody production to a T-dependent antigen and enhanced MHC class II antigen presentation to T helper cells by dendritic cells has been observed [98]. To the best of our knowledge, nothing is hitherto known about anemia, microcirculation and thrombosis in those mice.

\section{Conclusion}

Gedunin stimulates $\mathrm{Ca}^{2+}$ entry leading to cell shrinkage and cell membrane scrambling of erythrocytes, hallmarks of suicidal erythrocyte death or eryptosis.

\section{Acknowledgements}

The authors acknowledge the meticulous preparation of the manuscript by Tanja Loch. The study was supported by the Deutsche Forschungsgemeinschaft and the Open Access Publishing Fund of Tuebingen University.

\section{References}

1 Koriem KM: Review on pharmacological and toxicologyical effects of oleum azadirachti oil. Asian Pac J Trop Biomed 2013;3:834-840.

- Hieronymus H, Lamb J, Ross KN, Peng XP, Clement C, Rodina A, Nieto M, Du J, Stegmaier K, Raj SM, Maloney KN, Clardy J, Hahn WC, Chiosis G, Golub TR: Gene expression signature-based chemical genomic prediction identifies a novel class of HSP90 pathway modulators. Cancer Cell 2006;10:321-330.

-3 Patwardhan CA, Fauq A, Peterson LB, Miller C, Blagg BS, Chadli A: Gedunin inactivates the co-chaperone p23 protein causing cancer cell death by apoptosis. J Biol Chem 2013;288:7313-7325.

4 Brandt GE, Schmidt MD, Prisinzano TE, Blagg BS: Gedunin, a novel hsp90 inhibitor: semisynthesis of derivatives and preliminary structure-activity relationships. J Med Chem 2008;51:6495-6502.

5 Cazal CM, Choosang K, Severino VG, Soares MS, Sarria AL, Fernandes JB, Silva MF, Vieira PC, Pakkong P, Almeida GM, Vasconcelos MH, Nascimento MS, Pinto MM: Evaluation of effect of triterpenes and limonoids on cell growth, cell cycle and apoptosis in human tumor cell line. Anticancer Agents Med Chem 2010;10:769-776.

6 Kamath SG, Chen N, Xiong Y, Wenham R, Apte S, Humphrey M, Cragun J, Lancaster JM: Gedunin, a novel natural substance, inhibits ovarian cancer cell proliferation. Int J Gynecol Cancer 2009;19:1564-1569. 
7 Uddin SJ, Nahar L, Shilpi JA, Shoeb M, Borkowski T, Gibbons S, Middleton M, Byres M, Sarker SD: Gedunin, a limonoid from Xylocarpus granatum, inhibits the growth of CaCo-2 colon cancer cell line in vitro. Phytother Res 2007;21:757-761.

8 Kikuchi T, Ishii K, Noto T, Takahashi A, Tabata K, Suzuki T, Akihisa T: Cytotoxic and apoptosis-inducing activities of limonoids from the seeds of Azadirachta indica (neem). J Nat Prod 2011;74:866-870.

-9 Hullin-Matsuda F, Tomishige N, Sakai S, Ishitsuka R, Ishii K, Makino A, Greimel P, Abe M, Laviad EL, Lagarde M, Vidal H, Saito T, Osada H, Hanada K, Futerman AH, Kobayashi T: Limonoid compounds inhibit sphingomyelin biosynthesis by preventing CERT protein-dependent extraction of ceramides from the endoplasmic reticulum. J Biol Chem 2012;287:24397-24411.

10 Lee SE, Kim MR, Kim JH, Takeoka GR, Kim TW, Park BS: Antimalarial activity of anthothecol derived from Khaya anthotheca (Meliaceae). Phytomedicine 2008;15:533-535.

11 MacKinnon S, Durst T, Arnason JT, Angerhofer C, Pezzuto J, Sanchez-Vindas PE, Poveda LJ, Gbeassor M: Antimalarial activity of tropical Meliaceae extracts and gedunin derivatives. J Nat Prod 1997;60:336-341.

12 Lakshmi V, Srivastava S, Mishra SK, Srivastava MN, Srivastava K, Puri SK: Antimalarial activity in Xylocarpus granatum (Koen). Nat Prod Res 2012;26:1012-1015.

13 Miranda Junior RN, Dolabela MF, da Silva MN, Povoa MM, Maia JG: Antiplasmodial activity of the andiroba (Carapa guianensis Aubl., Meliaceae) oil and its limonoid-rich fraction. J Ethnopharmacol 2012;142:679683.

14 Omar S, Zhang J, MacKinnon S, Leaman D, Durst T, Philogene BJ, Arnason JT, Sanchez-Vindas PE, Poveda L, Tamez PA, Pezzuto JM: Traditionally-used antimalarials from the Meliaceae. Curr Top Med Chem 2003;3:133-139.

15 Lang E, Qadri SM, Lang F: Killing me softly - suicidal erythrocyte death. Int J Biochem Cell Biol 2012;44:1236-1243.

16 Lang PA, Kaiser S, Myssina S, Wieder T, Lang F, Huber SM: Role of $\mathrm{Ca}^{2+}$-activated $\mathrm{K}^{+}$channels in human erythrocyte apoptosis. Am J Physiol Cell Physiol 2003;285:C1553-C1560.

17 Bhavsar SK, Bobbala D, Xuan NT, Foller M, Lang F: Stimulation of suicidal erythrocyte death by alpha-lipoic acid. Cell Physiol Biochem 2010;26:859-868.

18 Foller M, Huber SM, Lang F: Erythrocyte programmed cell death. IUBMB Life 2008;60:661-668.

19 Foller M, Mahmud H, Gu S, Wang K, Floride E, Kucherenko Y, Luik S, Laufer S, Lang F: Participation of leukotriene C(4) in the regulation of suicidal erythrocyte death. J Physiol Pharmacol 2009;60:135-143.

20 Lau IP, Chen H, Wang J, Ong HC, Leung KC, Ho HP, Kong SK: In vitro effect of CTAB- and PEG-coated gold nanorods on the induction of eryptosis/erythroptosis in human erythrocytes. Nanotoxicology 2012;6:847856.

21 Maellaro E, Leoncini S, Moretti D, Del Bello B, Tanganelli I, De Felice C, Ciccoli L: Erythrocyte caspase-3 activation and oxidative imbalance in erythrocytes and in plasma of type 2 diabetic patients. Acta Diabetol 2013;50:489-495.

22 Foller M, Sopjani M, Koka S, Gu S, Mahmud H, Wang K, Floride E, Schleicher E, Schulz E, Munzel T, Lang F: Regulation of erythrocyte survival by AMP-activated protein kinase. FASEB J 2009;23:1072-1080.

-23 Kucherenko Y, Zelenak C, Eberhard M, Qadri SM, Lang F: Effect of casein kinase 1alpha activator pyrvinium pamoate on erythrocyte ion channels. Cell Physiol Biochem 2012;30:407-417.

24 Zelenak C, Eberhard M, Jilani K, Qadri SM, Macek B, Lang F: Protein kinase CK1alpha regulates erythrocyte survival. Cell Physiol Biochem 2012;29:171-180.

25 Foller M, Feil S, Ghoreschi K, Koka S, Gerling A, Thunemann M, Hofmann F, Schuler B, Vogel J, Pichler B, Kasinathan RS, Nicolay JP, Huber SM, Lang F, Feil R: Anemia and splenomegaly in cGKI-deficient mice. Proc Natl Acad Sci USA 2008;105:6771-6776.

26 Bhavsar SK, Gu S, Bobbala D, Lang F: Janus kinase 3 is expressed in erythrocytes, phosphorylated upon energy depletion and involved in the regulation of suicidal erythrocyte death. Cell Physiol Biochem 2011;27:547-556.

27 Klarl BA, Lang PA, Kempe DS, Niemoeller OM, Akel A, Sobiesiak M, Eisele K, Podolski M, Huber SM, Wieder T, Lang F: Protein kinase C mediates erythrocyte "programmed cell death" following glucose depletion. Am J Physiol Cell Physiol 2006;290:C244-C253.

28 Gatidis S, Zelenak C, Fajol A, Lang E, Jilani K, Michael D, Qadri SM, Lang F: p38 MAPK activation and function following osmotic shock of erythrocytes. Cell Physiol Biochem 2011;28:1279-1286. 
Lupescu et al.: Gedunin-Induced Eryptosis

29 Zelenak C, Foller M, Velic A, Krug K, Qadri SM, Viollet B, Lang F, Macek B: Proteome analysis of erythrocytes lacking AMP-activated protein kinase reveals a role of PAK2 kinase in eryptosis. J Proteome Res 2011;10:1690-1697.

-30 Lupescu A, Shaik N, Jilani K, Zelenak C, Lang E, Pasham V, Zbidah M, Plate A, Bitzer M, Foller M, Qadri SM, Lang F: Enhanced Erythrocyte Membrane Exposure of Phosphatidylserine Following Sorafenib Treatment: An in vivo and in vitro Study. Cell Physiol Biochem 2012;30:876-888.

-31 Shaik N, Lupescu A, Lang F: Sunitinib-sensitive suicidal erythrocyte death. Cell Physiol Biochem 2012;30:512-522.

-32 Abed M, Towhid ST, Mia S, Pakladok T, Alesutan I, Borst O, Gawaz M, Gulbins E, Lang F: Sphingomyelinaseinduced adhesion of eryptotic erythrocytes to endothelial cells. Am J Physiol Cell Physiol 2012;303:C991999.

33 Abed M, Towhid ST, Shaik N, Lang F: Stimulation of suicidal death of erythrocytes by rifampicin. Toxicology 2012;302:123-128.

34 Bottger E, Multhoff G, Kun JF, Esen M: Plasmodium falciparum-infected erythrocytes induce granzyme B by NK cells through expression of host-Hsp70. PLoS One 2012;7:e33774.

35 Firat U, Kaya S, Cim A, Buyukbayram H, Gokalp O, Dal MS, Tamer MN: Increased caspase-3 immunoreactivity of erythrocytes in STZ diabetic rats. Exp Diabetes Res 2012;2012:316384.

36 Ganesan S, Chaurasiya ND, Sahu R, Walker LA, Tekwani BL: Understanding the mechanisms for metabolism-linked hemolytic toxicity of primaquine against glucose 6-phosphate dehydrogenase deficient human erythrocytes: evaluation of eryptotic pathway. Toxicology 2012;294:54-60.

37 Gao M, Cheung KL, Lau IP, Yu WS, Fung KP, Yu B, Loo JF, Kong SK: Polyphyllin D induces apoptosis in human erythrocytes through $\mathrm{Ca}^{2+}$ rise and membrane permeabilization. Arch Toxicol 2012;86:741-752.

-38 Ghashghaeinia M, Cluitmans JC, Akel A, Dreischer P, Toulany M, Koberle M, Skabytska Y, Saki M, Biedermann T, Duszenko M, Lang F, Wieder T, Bosman GJ: The impact of erythrocyte age on eryptosis. Br J Haematol 2012;157:606-614.

-39 Jilani K, Lupescu A, Zbidah M, Abed M, Shaik N, Lang F: Enhanced Apoptotic Death of Erythrocytes Induced by the Mycotoxin Ochratoxin A. Kidney Blood Press Res 2012;36:107-118.

40 Jilani K, Lupescu A, Zbidah M, Shaik N, Lang F: Withaferin A-stimulated Ca2+ entry, ceramide formation and suicidal death of erythrocytes. Toxicol In Vitro 2013;27:52-58.

-41 Kucherenko YV, Lang F: Inhibitory Effect of Furosemide on Non-Selective Voltage-Independent Cation Channels in Human Erythrocytes. Cell Physiol Biochem 2012;30:863-875.

42 Lang E, Qadri SM, Jilani K, Zelenak C, Lupescu A, Schleicher E, Lang F: Carbon monoxide-sensitive apoptotic death of erythrocytes. Basic Clin Pharmacol Toxicol 2012;111:348-355.

43 Lupescu A, Jilani K, Zbidah M, Lang E, Lang F: Enhanced $\mathrm{Ca}^{2+}$ entry, ceramide formation, and apoptotic death of erythrocytes triggered by plumbagin. J Nat Prod 2012;75:1956-1961.

44 Lupescu A, Jilani K, Zbidah M, Lang F: Induction of apoptotic erythrocyte death by rotenone. Toxicology 2012;300:132-137.

45 Lupescu A, Jilani K, Zelenak C, Zbidah M, Qadri SM, Lang F: Hexavalent chromium-induced erythrocyte membrane phospholipid asymmetry. Biometals 2012;25:309-318.

46 Polak-Jonkisz D, Purzyc L: Ca Influx versus Efflux during Eryptosis in Uremic Erythrocytes. Blood Purif 2012;34:209-210.

47 Qian EW, Ge DT, Kong SK: Salidroside protects human erythrocytes against hydrogen peroxide-induced apoptosis. J Nat Prod 2012;75:531-537.

48 Shaik N, Zbidah M, Lang F: Inhibition of $\mathrm{Ca}^{2+}$ entry and suicidal erythrocyte death by naringin. Cell Physiol Biochem 2012;30:678-686.

49 Vota DM, Maltaneri RE, Wenker SD, Nesse AB, Vittori DC: Differential erythropoietin action upon cells induced to eryptosis by different agents. Cell Biochem Biophys 2013;65:145-157.

50 Weiss E, Cytlak UM, Rees DC, Osei A, Gibson JS: Deoxygenation-induced and $\mathrm{Ca}^{2+}$ dependent phosphatidylserine externalisation in red blood cells from normal individuals and sickle cell patients. Cell Calcium 2012;51:51-56.

-51 Zappulla D: Environmental stress, erythrocyte dysfunctions, inflammation, and the metabolic syndrome: adaptations to CO2 increases? J Cardiometab Syndr 2008;3:30-34.

52 Zbidah M, Lupescu A, Jilani K, Lang F: Stimulation of suicidal erythrocyte death by fumagillin. Basic Clin Pharmacol Toxicol 2013;112:346-351. 
53 Zbidah M, Lupescu A, Shaik N, Lang F: Gossypol-induced suicidal erythrocyte death. Toxicology 2012;302:101-105.

54 Zelenak C, Pasham V, Jilani K, Tripodi PM, Rosaclerio L, Pathare G, Lupescu A, Faggio C, Qadri SM, Lang F: Tanshinone IIA stimulates erythrocyte phosphatidylserine exposure. Cell Physiol Biochem 2012;30:282294.

55 Abed M, Herrmann T, Alzoubi K, Pakladok T, Lang F: Tannic Acid induced suicidal erythrocyte death. Cell Physiol Biochem 2013;32:1106-1116.

56 Ahmed MS, Langer H, Abed M, Voelkl J, Lang F: The uremic toxin acrolein promotes suicidal erythrocyte death. Kidney Blood Press Res 2013;37:158-167.

57 Ghashghaeinia M, Cluitmans JC, Toulany M, Saki M, Koberle M, Lang E, Dreischer P, Biedermann T, Duszenko M, Lang F, Bosman GJ, Wieder T: Age Sensitivity of NFkappaB Abundance and Programmed Cell Death in Erythrocytes Induced by NFkappaB Inhibitors. Cell Physiol Biochem 2013;32:801-813.

58 Abed M, Feger M, Alzoubi K, Pakladok T, Frauenfeld L, Geiger C, Towhid ST, Lang F: Sensitization of erythrocytes to suicidal erythrocyte death following water deprivation. Kidney Blood Press Res 2013;37:567-578.

59 Alzoubi K, Honisch S, Abed M, Lang F: Triggering of Suicidal Erythrocyte Death by Penta-O-galloyl-beta-dglucose. Toxins (Basel) 2014;6:54-65.

60 Jilani K, Qadri SM, Lang F: Geldanamycin-induced phosphatidylserine translocation in the erythrocyte membrane. Cell Physiol Biochem 2013;32:1600-1609.

61 Jilani K, Lang F: Carmustine-induced phosphatidylserine translocation in the erythrocyte membrane. Toxins (Basel) 2013;5:703-716.

62 Jilani K, Enkel S, Bissinger R, Almilaji A, Abed M, Lang F: Fluoxetine induced suicidal erythrocyte death. Toxins (Basel) 2013;5:1230-1243.

-63 Bissinger R, Modicano P, Frauenfeld L, Lang E, Jacobi J, Faggio C, Lang F: Estramustine-induced suicidal erythrocyte death. Cell Physiol Biochem 2013;32:1426-1436.

64 Lupescu A, Jilani K, Zbidah M, Lang F: Patulin-induced suicidal erythrocyte death. Cell Physiol Biochem 2013;32:291-299.

65 Lupescu A, Bissinger R, Jilani K, Lang F: Triggering of suicidal erythrocyte death by celecoxib. Toxins (Basel) 2013;5:1543-1554.

66 Lang E, Modicano P, Arnold M, Bissinger R, Faggio C, Abed M, Lang F: Effect of thioridazine on erythrocytes. Toxins (Basel) 2013;5:1918-1931.

67 Ekambaram P, Jayachandran T, Dhakshinamoorthy L: Differential expression of HSP90alpha and heme oxygenase in cord blood RBC during preeclampsia. Toxicol Mech Methods 2013;23:113-119.

68 Mirjana M, Jelena A, Aleksandra U, Svetlana D, Nevena G, Jelena M, Goran P, Melita V: Alpha-lipoic acid preserves the structural and functional integrity of red blood cells by adjusting the redox disturbance and decreasing O-GlcNAc modifications of antioxidant enzymes and heat shock proteins in diabetic rats. Eur J Nutr 2012;51:975-986.

69 Bauersfeld W, Knoll E, Wisser H: [Analytical and technical reliability of the ELT-8 laser hematologic counter]. J Clin Chem Clin Biochem 1985;23:215-223.

-70 Niemoeller OM, Akel A, Lang PA, Attanasio P, Kempe DS, Hermle T, Sobiesiak M, Wieder T, Lang F: Induction of eryptosis by cyclosporine. Naunyn Schmiedebergs Arch Pharmacol 2006;374:41-49.

71 Rosenbaum EE, Brehm KS, Vasiljevic E, Liu CH, Hardie RC, Colley NJ: XPORT-dependent transport of TRP and rhodopsin. Neuron 2011;72:602-615.

72 Harrison HE, Bunting H, Ordway NK, Albrink WS: The Pathogenesis of the Renal Injury Produced in the Dog by Hemoglobin or Methemoglobin. J Exp Med 1947;86:339-356.

73 Dubois C, Vanden Abeele F, Prevarskaya N: Targeting apoptosis by the remodelling of calcium-transporting proteins in cancerogenesis. FEBS J 2013;280:5500-5510.

74 Orrenius S, McCabe MJ, Jr., Nicotera P: $\mathrm{Ca}^{2+}$-dependent mechanisms of cytotoxicity and programmed cell death. Toxicol Lett 1992;64-65 Spec No:357-364.

75 Schwarz EC, Qu B, Hoth M: Calcium, cancer and killing: the role of calcium in killing cancer cells by cytotoxic T lymphocytes and natural killer cells. Biochim Biophys Acta 2013;1833:1603-1611.

76 Foller M, Bobbala D, Koka S, Huber SM, Gulbins E, Lang F: Suicide for survival--death of infected erythrocytes as a host mechanism to survive malaria. Cell Physiol Biochem 2009;24:133-140. 
Lupescu et al.: Gedunin-Induced Eryptosis

77 Duranton C, Huber S, Tanneur V, Lang K, Brand V, Sandu C, Lang F: Electrophysiological properties of the Plasmodium Falciparum-induced cation conductance of human erythrocytes. Cell Physiol Biochem 2003;13:189-198.

78 Kirk K: Membrane transport in the malaria-infected erythrocyte. Physiol Rev 2001;81:495-537.

79 Ayi K, Giribaldi G, Skorokhod A, Schwarzer E, Prendergast PT, Arese P: 16alpha-bromoepiandrosterone, an antimalarial analogue of the hormone dehydroepiandrosterone, enhances phagocytosis of ring stage parasitized erythrocytes: a novel mechanism for antimalarial activity. Antimicrob Agents Chemother 2002;46:3180-3184.

80 Ayi K, Turrini F, Piga A, Arese P: Enhanced phagocytosis of ring-parasitized mutant erythrocytes: a common mechanism that may explain protection against falciparum malaria in sickle trait and beta-thalassemia trait. Blood 2004;104:3364-3371.

81 Cappadoro M, Giribaldi G, O'Brien E, Turrini F, Mannu F, Ulliers D, Simula G, Luzzatto L, Arese P: Early phagocytosis of glucose-6-phosphate dehydrogenase (G6PD)-deficient erythrocytes parasitized by Plasmodium falciparum may explain malaria protection in G6PD deficiency. Blood 1998;92:2527-2534.

82 Bunn HF: The triumph of good over evil: protection by the sickle gene against malaria. Blood 2013;121:2025.

83 Wautier JL, Wautier MP: Molecular basis of erythrocyte adhesion to endothelial cells in diseases. Clin Hemorheol Microcirc 2013;53:11-21.

84 van Zwieten R, Verhoeven AJ, Roos D: Inborn defects in the antioxidant systems of human red blood cells. Free Radic Biol Med 2014;67:377-386.

85 Taylor SM, Cerami C, Fairhurst RM: Hemoglobinopathies: slicing the Gordian knot of Plasmodium falciparum malaria pathogenesis. PLoS Pathog 2013;9:e1003327.

-86 Koka S, Foller M, Lamprecht G, Boini KM, Lang C, Huber SM, Lang F: Iron deficiency influences the course of malaria in Plasmodium berghei infected mice. Biochem Biophys Res Commun 2007;357:608-614.

-87 Koka S, Huber SM, Boini KM, Lang C, Foller M, Lang F: Lead decreases parasitemia and enhances survival of Plasmodium berghei-infected mice. Biochem Biophys Res Commun 2007;363:484-489.

-88 Koka S, Lang C, Boini KM, Bobbala D, Huber SM, Lang F: Influence of chlorpromazine on eryptosis, parasitemia and survival of Plasmodium berghe infected mice. Cell Physiol Biochem 2008;22:261-268.

-89 Koka S, Lang C, Niemoeller OM, Boini KM, Nicolay JP, Huber SM, Lang F: Influence of NO synthase inhibitor L-NAME on parasitemia and survival of Plasmodium berghei infected mice. Cell Physiol Biochem 2008;21:481-488.

-90 Andrews DA, Low PS: Role of red blood cells in thrombosis. Curr Opin Hematol 1999;6:76-82.

91 Borst O, Abed M, Alesutan I, Towhid ST, Qadri SM, Foller M, Gawaz M, Lang F: Dynamic adhesion of eryptotic erythrocytes to endothelial cells via CXCL16/SR-PSOX. Am J Physiol Cell Physiol 2012;302:C644-C651.

92 Closse C, Dachary-Prigent J, Boisseau MR: Phosphatidylserine-related adhesion of human erythrocytes to vascular endothelium. Br J Haematol 1999;107:300-302.

93 Gallagher PG, Chang SH, Rettig MP, Neely JE, Hillery CA, Smith BD, Low PS: Altered erythrocyte endothelial adherence and membrane phospholipid asymmetry in hereditary hydrocytosis. Blood 2003;101:46254627.

$\$ 94$ Pandolfi A, Di Pietro N, Sirolli V, Giardinelli A, Di Silvestre S, Amoroso L, Di Tomo P, Capani F, Consoli A, Bonomini M: Mechanisms of uremic erythrocyte-induced adhesion of human monocytes to cultured endothelial cells. J Cell Physiol 2007;213:699-709.

-95 Wood BL, Gibson DF, Tait JF: Increased erythrocyte phosphatidylserine exposure in sickle cell disease: flowcytometric measurement and clinical associations. Blood 1996;88:1873-1880.

-96 Chung SM, Bae ON, Lim KM, Noh JY, Lee MY, Jung YS, Chung JH: Lysophosphatidic acid induces thrombogenic activity through phosphatidylserine exposure and procoagulant microvesicle generation in human erythrocytes. Arterioscler Thromb Vasc Biol 2007;27:414-421.

-97 Zwaal RF, Comfurius P, Bevers EM: Surface exposure of phosphatidylserine in pathological cells. Cell Mol Life Sci 2005;62:971-988.

\$8 Li Y, Li S, Hoshino M, Ishikawa R, Kajiwara C, Gao X, Zhao Y, Ishido S, Udono H, Wang JY: HSP90alpha deficiency does not affect immunoglobulin gene hypermutation and class switch but causes enhanced MHC class II antigen presentation. Int Immunol 2012;24:751-758. 